\title{
Phytochemical Analysis and Acute Toxicity (LD50) Studies of Aqueous Seed Extract of Irvingia gabonensis (African mango)
}

\author{
Muhammad Ibrahim Usman ${ }^{1 *}$, Abubakar Bilyaminu Mu'azu ${ }^{1}$ Yunusa Abdulmumin ${ }^{2}$, Jazuli Farida Usman ${ }^{3}$ and \\ Abdulrashid Mohammed ${ }^{4}$ \\ ${ }^{1}$ Department of Medical Biochemistry, College of Medical Sciences, Yobe State University Damaturu, Yobe. \\ Nigeria. \\ ${ }^{2}$ Department of Biochemistry, Faculty of Sciences, Kano State University of Science and Technology Wudil, \\ Kano, Nigeria. \\ ${ }^{3}$ Department of Biochemistry, Faculty of Basic Medical Sciences, Bayero University, P. M. B. 3011, Kano, \\ Nigeria. \\ ${ }^{4}$ Department of Biochemistry, College of Medical Sciences, Abubakar Tafawa Balewa University, P.M.B 0248, \\ Bauchi. Nigeria.
}

Corresponding Author: Muhammad Ibrahim Usman

Email: ibrahimmuhd@yahoo.com

\begin{abstract}
African mango (Irvingia gabonensis) belongs to the Irvingiaceae family of plants, it has a long history both as a food and medicine. This study was carried out to analyze the phytochemicals of seed extract as well as to evaluate its acute oral toxicity $\left(\mathrm{LD}_{50}\right)$. A total of thirteen rats were used for the acute toxicity study and was done in two phases; in phase I, nine rats were divided into three groups of three rats each and were orally administered with 10,100 and $1000 \mathrm{mg} / \mathrm{kg}$ body weight of the extract. The rats were observed for mortality and general behavior for $24 \mathrm{hrs}$. In phase II, four rats were administered with the extract at higher doses of 1500, 2500, 3500 and $5000 \mathrm{mg} / \mathrm{kg}$ respectively and were observed for mortality and other signs of toxicity for $24 \mathrm{hrs}$. The results of the qualitative phytochemical analysis revealed the presence of alkaloids, flavonoids, glycoside, saponin, tannins, resins and reducing sugar with the absence of coumarin, while quantitative analysis shows that the extract is rich in glycosides, followed by flavonoids, followed by alkaloids, followed by saponin, and lastly tannin A and tannin B. Acute toxicity revealed that the extract was practically nontoxic with oral $\mathrm{LD}_{50}$ greater than $5000 \mathrm{mg} / \mathrm{kg}$ body weight. In conclusion, these results showed that the extract is rich in phytochemicals and was found to be relatively safe at administered doses.
\end{abstract}

Keywords: acute toxicity; Irvingia gabonensis; phytochemical analysis and seed extract.

DOI: $10.7176 / \mathrm{JBAH} / 9-24-07$

Publication date: December $31^{\text {st }} 2019$

\subsection{INTRODUCTION}

African mango (Irvingia gabonensis) belongs to the Irvingiaceae family of plants. The plant bears a fruit that is yellow when ripe with an edible sweet, smooth and brittle pulp which is slightly slimy with a turpentine flavor. It can be eaten fresh or used in preparation of wine, jam, juice and jelly. The seed ranks as an oil seed used as a popular soup and stew thickener in Nigeria. In Nupe it is called "Pekpeara" "ogbono/ogiri" in Igbo, "Goro biri" in Hausa and "Oro" (tree) "Aapon" (kernel) in Yoruba. The kernels are also made into a cake called 'Dika bread' or 'Odika bread' for year-round preservation and easy use (Tchoundjeu and Atangana, 2007). Edible oil extracted from the seed is used in cooking and as a substitute for cocoa butter. Matos et al (2009) reported that the margarine based on I. gabonensis oil is an alternative to the trans-fatty acids obtained during hydrogenation and other reactions used in margarine production. It is also used in manufacture of pharmaceuticals and cosmetics.

There is an assumption that that the use of plants in traditional medical practice for treatment of various ailments is harmless and safe because they are derived from natural sources (Alli et al., 2015) This assumption is based on the common belief that herbs are by nature safer and gentler than orthodox drugs and plant-based medicine have been used in the treatment of diseases over many centuries (Newman and Cragg, 2007). However, herbal preparations assumed to be safe may contain contaminants such as pathogenic microbes, heavy metals and aflatoxins due to the manner in which they are prepared (Dusanee et al., 2007) Moreover, many studies have 
reported various toxic effects of herbal medicines, such as hepatotoxicity (Nwachukwu and Iweala, 2009) and nephrotoxicity (Asif, 2012).

The current study was conducted to investigate the phytochemical composition, and determining the acute $\left(\mathrm{LD}_{50}\right)$ toxicity of Irvingia gabonensis aqueous seed extract in albino rats.

\subsection{MATERIALS AND METHODS}

\subsection{Study Animals}

Albino rats (both male and female) weighing $120 \mathrm{~g}$ were obtained from Department of Biological Sciences, Bayero University Kano. Animals were housed in colony cages at an ambient temperature and relative humidity. The animals had free access to standard palletized grower feed and drinking water. The principles of laboratory animal care and guidelines were followed.

\subsection{Collection and Extraction of the Plant Material}

Irvengia gabonensis seeds were bought from Yanlemo fruit market Zaria road Kano, they were shade dried in shade and ground into powder form out of which $100 \mathrm{~g}$ of the powder was weighed and soaked in $500 \mathrm{~cm}^{3}$ of distilled water for 24 hours. Thereafter, the solution was filtered and $10 \mathrm{ml}$ of the filtrate was evaporated to dryness in an oven at $40^{\circ} \mathrm{C}$ to produce a dark brown residue. The residue was weighed and the concentration of the filtrate was found to be $200 \mathrm{mg} / \mathrm{ml}$. This was administered to the animals according to the required dose using the relation (Muhammad et al., 2016).

\subsection{Phytochemical screening}

Phytochemical tests were carried out by using the standard methods of Harborne (1973), Sofowora (1993), Trease and Evans (1989), Kokate (2003), Rasal (2005) and Savithramma et al (2011).

\subsection{Lethal mean dose (LD50) determination}

The median lethal dose $\left(\mathrm{LD}_{50}\right)$ determination was conducted using the method of Lorke (1983) through the oral route in rats in two different phases. Thirteen albino rats were used for this study. The study was done in two phases; in phase I, nine rats were divided into three groups of three rats each and were orally administered the extract at different doses of 10,100 and $1000 \mathrm{mg} / \mathrm{kg}$ body weight. The rats were observed for mortality and general behavior for $24 \mathrm{hrs}$. In phase II, four rats were administered with the extract at higher doses of $1500,2500,3500$ and $5000 \mathrm{mg} / \mathrm{kg}$ and were observed for mortality and other signs of toxicity for $24 \mathrm{hrs}$.

\subsection{Statistical Analysis}

Results were expressed as mean \pm standard deviation. The data collected were subjected to one-way Analysis of Variance (ANOVA) using Graphad Instat, Version 3.02. (San Diego, USA)

\subsection{RESULTS AND DISCUSSION \\ 3.1 Results}

3.1.1 Phytochemical screening

The results of the qualitative and quantitative phytochemical screening of aqueous seeds extract of Irvengia gabonensis were presented in Table 1. The results of the qualitative analysis shows the presence of alkaloids, flavonoids, glycoside, saponin, tannins, resins and reducing sugar, while quantitative analysis shows that the extract is rich in sterols, followed by glycosides, then flavonoids, then alkaloids, followed by saponin, tannin A and tannin B respectively.

Table 2: Phytochemical screening of the aqueous seeds extract of Irvengia gabonensis

\begin{tabular}{lcc}
\hline Phytochemical constituents & Inference & Content (\%) \\
\hline Alkaloids & + & $0.072 \pm 0.017$ \\
Tritepeniod & - & - \\
Flavonoids & + & $1.05 \pm 0.051$ \\
Glycosides(cardiac) & + & $1.59 \pm 0.082$ \\
Saponin & + & $0.324 \pm 0.065$ \\
Sterols & + & $2.09 \pm 0.54$ \\
Tannin A & + & $0.38 \pm 0.067$ \\
Tanin B & + & $0.31 \pm 0.043$ \\
Coumarin & - & - \\
\hline
\end{tabular}

Key; (+) means present, (-) means not detected. Values are expressed as Mean \pm SEM. 


\subsubsection{Acute toxicity studies}

Table two and three shows the results for $\mathrm{LD}_{50}$ determination, in both phases no signs of toxicity or mortality were observed at the doses up to $5000 \mathrm{mg} / \mathrm{kg}$ for 24 hours of the extract administration.

Table 3: Phase I LD ${ }_{50}$, (Oral, rat) of the aqueous seeds extract of Irvengia gabonensis

\begin{tabular}{ll}
\hline Doses $(\mathrm{mg} / \mathrm{kg})$ & Result \\
\hline 10 & $0 / 3$ \\
100 & $0 / 3$ \\
1000 & $0 / 3$ \\
\hline
\end{tabular}

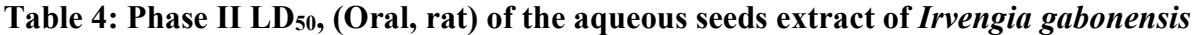

\begin{tabular}{ll}
\hline Doses $(\mathrm{mg} / \mathrm{kg})$ & Result \\
\hline 1500 & $0 / 1$ \\
2500 & $0 / 1$ \\
3500 & $0 / 1$ \\
5000 & $0 / 1$ \\
\hline
\end{tabular}

\subsection{Discussion}

The detected phytochemicals obtained from screening of aqueous seed extract of Irvengia gabonensis are flavonoids, alkaloids, cardiac glycosides, saponins, sterols and tannins. The quantitative phytochemical screening shows a high concentration of flavonoids, saponins, tannins alkaloids, cardiac glycoside and sterols. Phytochemicals have been reported to mediate the medicinal activity of various plant extracts (Toma et al., 2009). The phenol content of the African mango seed may be responsible for the reported radical scavenging activity by Nixwell et al (2013).

Tannins were also reported to possess free-radical scavenging activity, antimicrobial, antiviral and antiinflammatory properties (Akiyama et al., 2001). Thus, the detection of tannins in the extracts indicates the potential health benefits of the fruits as acclaimed by the local populace. Saponins are common in most plants and have been postulated to have a wide range of biological activity including antioxidant, anticarcinogenic as well as having immunostimulant properties thereby exhibiting the potential to cure a number of diseases (Trease and Evans, 2002). Usunomena (2012) reported the importance of cardiac glycosides in treating congestive heart failure thus its presence in these fruits is much desired.

The presence of sterols in African mango seeds support the research reported by Amarasinghe et al (2008). This was corroborated by De Stafani et al (2000) who in a controlled case-study experiment showed the consumption of plant sterols to be inversely proportional to the occurrence of stomach cancer. Varadharajan et al (2012) also reported sterols to have wound healing properties- a potential that makes their presence in foods desirable.

The results of the $\mathrm{LD}_{50}$ studies does not show any sign of toxicity or mortality up to a higher dose of $5000 \mathrm{mg} / \mathrm{kg}$. The result of the acute toxicity study indicated that the plant is practically nontoxic according to Hodge and Staner Scale (2005). This is in accordance with a study by Shah et al (1998) who demonstrated that ethanol extract of Cinnamomum zeynalicum bark was non-toxic after acute toxicity tests. Thus the low toxicity of Irvengia gabonensis offers a wide margin of safety for beneficial doses in therapeutics.

\subsection{CONCLUSION}

The research concludes that Irvengia gabonensis aqueous seed extract is rich in phytochemicals that were reported to possess various pharmacological activities. It was also established that the extract is practically non-toxic, evidenced by high $\mathrm{LD}_{50}$ value with no lethality.

\section{Reference:}

Akiyama, H., Fuji K., Yamasaki, O., Oono, T. and Iwatsuki, K. (2001). Antibacterial action of several tannins against Staphylococcus aureus. Journal of Antimicrobial Chemotherapy 48 (4):487 - 491.

Alli, L.A., Adesokan, A.A., Salawu, O.A and Akanji, M.A. (2015). Toxicological studies of aqueous extract of Acacia nilotica root. Interdisciplinary Toxicology. 8(1): 48-54. 
Amarasinghe, N.R., Jayasinghe, L., Hara, N. and Fujimoto, Y. (2008). Chemical constituents of the fruits of Artocarpus altilis. Biochemical Systematics and Ecology. 36 (4):323 - 325.

Asif, M. (2012). A brief study of toxic effects of some medicinal herbs on kidney. Adv Biomed Res. 1: 44-47.

Dusanee, T., Yaowapa, S., Prapaporn, S., Saowalak, S., Oraphan, P. and Sittichai, C. (2007). Inhibitory Effect of Essential Oils on the Growth of Aspergillus flavus. Sci. Tech. J. 7: 1-7.

Harborne, J.B. (1973). Phytochemical Methods, London Chapman and Hall Ltd. Pp. 49-188.

Hodge and Staner Scale (2005). Toxicity Classes. In Canadian Center for Occupational HealthandSafety.CopyRight19972010.http://www.Ccohs.Ca/Oshanswers/Chemicals/ld50.Html

Kokate, C.K. (2003). Practical Pharmacognosy. Pune: Vallabh Prakashan.

Lorke, D. (1983). A New approach to practical acute toxicity testing. Archive of toxicology. 53:275-287.

Matos L, Nzikou JM, Matouba EV, Pandzou- Yembe N, Linder TM, Desobry S.(2009). Studies of Irvingia gabonensis Seed Kernels: Oil Technological Applications ENSP-UMNG, Laboratoire de Physico-chimie et de Biotechnologie Alimentaires. Pakistan Journal of Nutrition. 8 (2): 151-57.

Muhammad I. U., Alhassan A. J., Sule M. S., Idi A., Mohammed A., El- ta'alu A. B., Dangambo M.A. and Abdulmumin Y. (2016). Anti-Hyperglycemic Activity of Solvents Extract of Khaya senegalensis Stem Bark in Alloxan Induced Diabetic Rats. Journal of Advances in Biology \& Biotechnology 6(2): 1-8

Newman, D.J. and Cragg, G.M. (2007). Natural products as sources of new drugs over the last 25 years. $J$ Nat Prod. 70: 461-477.

Nixwell, M. F., Johanna, M. P. and Ngezimana, W. (2013). Proximate, chemical compositions and sulphur concentrations on quality of selected dried mango (Mangifera indica L.). African Journal of Biotechnology 12 (19): 2678 - 2684.

Nwachukwu, N. and Iweala, E.J. (2009). Influence of extraction methods on the hepatotoxicity of Azadirachta indica bark extract on albino rats. Global J Pure Appl Sci. 15(3): 369-372.

Rasal, V.P. (2005). Screening Shorea robesta Geartn F. for burnealing and antioxidant activities. M. Pharm. Thesis. K.L.E.S.’s College of Pharmacy, Belgaum, Karnataka, India.

Savithramma, N., Rao, M.L. and Suhrulatha, D. (2011). Screening of medicinal plants for secondary metabolites. Midlle-East Journal of Scientific Research, 8(3): 579-584.

Shah, A. H., Al-Shareef, A. H., Ageel, A. M. \& Qureshi, S. (1998). Toxicity studies in mice of common spices, Cinnamomum zeylanicum bark and Piper longum fruits. Plant Foods for Human Nutrition (Formerly Qualitas Plantarum), 52(3): 231-239

Sofowora, A. (1993). Medicinal Plants and Traditional Medicine in Africa. Spectrum Books Ltd, Ibadan, Nigeria. Pp. 289.

Tchoundjeu Z, Atangana A.R. (2007). Irvingia gabonensis (Aubry-Lecomte ex O'Rorke) Baill. In: van der Vossen, H.A.M. \& Mkamilo, G.S. (Editors). PROTA 14: Vegetable oils/Oléagineux. [CD- Rom]. PROTA, Wageningen, Netherlands.

Toma, I., Karumi, Y., and Geidam, M., A. (2009). Phytochemical screening and toxicity studies of the aqeous extract of the pods pulp of Cassia sieberiana D.C. African Journal of Pure and Applied Chemisty. 3(2). 026-030

Trease, G.E. and Evans, W.C. (1989). Pharmacognosy. A physician guide to herbal medicine, 11edn. Ballere Tindal, London, UK, Pp 530. 
Usunomena, U. (2012). A Review of some African medicinal plants. International Journal of Pharmacology and Biosciences. 3(4): 1 - 11.

Varadharajan, V., Janarthanan U.K. and Krishnamurthy, V. (2012). Physicochemical, phytochemical screening and profiling of secondary metabolites of Annona squamosa leaf extract. World Journal of Pharmaceutical Research 1 (4): 1143 - 1164. 